\title{
Flower morphology and ontogeny of endemic Crataegus tanacetifolia (Lam.) Pers. (Rosaceae) from Turkey
}

\author{
Aslthan ÇETINBAŞ GENÇ ${ }^{*} \oplus$, Meral ÜNAL ${ }^{2} \oplus$ \\ ${ }^{1,2}$ Marmara University, Faculty of Arts and Science, Department of Biology, Istanbul, Turkey \\ *aslihan.cetinbas@marmara.edu.tr, ${ }^{2}$ meralunal@marmara.edu.tr
}

Received : 27.03.2020

Accepted : 21.05.2020

Online : :07.09.2020

\section{Türkiye endemiği Crataegus tanacetifolia (Lam.) Pers.' in (Rosaceae) çiçek morfolojisi ve ontogenisi}

\begin{abstract}
In this study, flower morphology and ontogeny of Turkish endemic Crataegus tanacetifolia (Lam.) Pers. (Rosaceae) were studied using stereo, light and scanning electron microscope. Crataegus tanacetifolia has corymb type of inflorescence which bears 5-10 hermaphrodite flowers. The first sign in appearance of the flowers is the differentiation of apical meristem as a roundish bulge. It transforms into the floral meristem which gives rise to floral organ primordia in advanced stages. Twenty stamen primordia differentiate as roundish bulge from the sides of floral meristem. Subsequently, the stamen primordia start stretching and differantiating into filaments and anthers respectively. After a short time of stamen initiation, 5 carpel primordia differentiate from the floral meristem. In following stages, the carpel primordia elongate and form an ovary with 5 loculi. During the ovary formation, 5 styles occur on the ovary and then stigmas evolve out of styles tips.

Key words: apical merisem, Crataegus tanacetifolia, floral meristem, floral organ development, ontogeny

Özet: Bu çalışmada, Türkiye endemiği Crataegus tanacetifolia (Lam.) Pers.'in (Rosaceae) çiçek morfolojisi ve ontogenisi stereo, 1şı ve tarayıcı elektron mikroskobu ile incelenmiştir. Crataegus tanacetifolia 5-10 adet hermafrodit çiçek taşıyan korimbus tipi çiçek durumuna sahiptir. Çiçeklerin ortaya çıkışındaki ilk işaret, apikal meristemin yuvarlak bir çıkıntı olarak farklılaşmasıdır. Apikal meristem ilerleyen evrelerde çiçek organlarını oluşturacak olan floral meristeme dönüşür. Floral meristemin kenarlarından 20 adet stamen taslağı yuvarlak çıkıntılar olarak farklılaşır. Ardından stamen taslakları uzamaya başlar ve sırası ile filamentler ve anterleri oluşturur. Stamen taslaklarının belirmesinden kısa bir süre sonra, floral meristemden 5 adet karpel taslağı farklılaşır. İlerleyen evrelerde, karpel taslakları uzar ve 5 lokuslu bir ovaryum oluşturur. Ovaryum oluşumu esnasında, 5 stilus ovaryumun üzerinde gelişir ve ardından stilusların üzerinde stigmalar geişir.
\end{abstract}

Anahtar Kelimeler: apikal meristem, Crataegus tanacetifolia, floral meristem, çiçek organ gelişimi, ontogeni

Citation: Çetinbaş Genç A, Ünal M (2020). Flower morphology and ontogeny of endemic Crataegus tanacetifolia (Lam.) Pers. (Rosaceae) from Turkey. Anatolian Journal of Botany 4(2): 80-84.

\section{Introduction}

The genus Crataegus L. belongs to the subfamily Maloideae of Rosaceae and comprises approximately 200 species worldwide (Campbell et al., 2007; Benli et al., 2008). The homeland of Crataegus is Asian and Mediterranean Countries. According to Davis and Browicz (1972), there are 17 species, a subspecies, two varieties and dozens of hybrids, naturally grown in Turkey. Crataegus is characterised by a corymb which is a specialised determinate inflorescence containing a few to numerous of flowers (Dönmez, 2004). The inflorescence of Crataegus has one type of flower on a single corymb; hermaphrodite. Androecium consist of 5-60 stamens (Rohrer and Robertson, 1994) and gynoecium have 1-5 pistils (Dönmez, 2004). Crataegus species are important medicinal plants. They have been used as multi-effect traditional medicine for prevention and treatment of heart disease, insomnia and hypertension (Vitalini et al., 2009; Chang et al., 2005; Tassell et al., 2010; Dong et al., 2017). Also, they are economically important plants being used in cosmetics and food industry (Lund et al., 2017).

Sex determination in plants is among the most significant subjects that concern biologists due to the importance of reproduction and fertilization for genetical diversity. Also, flower organogenesis is a major area of plant developmental biology, because it is being one of the main basic topics and the reproductive character and the features of reproductive organs are systematically essential (Kinney et al., 2008). The basic bisexual flower is subdivided into four whorls. Whorl 1 and whorl 2 compose the sterile parts of flower and sex determination takes place in whorls 3 and 4, which contain stamens and pistils respectively (Dellaporta and Calderon-Urrea, 1993). However, the development pattern on the whorls differs between the sexes of flowers; hermaphrodite, pistillate, staminate. The start of flower bud development comprises the conversion of the vegetative meristem into the apical meristem and the transformation of the apical meristem into the floral meristem in the upcoming stage. Floral organs; sepal, petal, stamen and carpel develop from floral meristem, but further development of stamen or pistil is selective, resulting in unisexual flowers (Çetinbaş and Ünal, 2012).

Crataegus tanacetifolia (Lam.) Pers. is an important species, endemic to Turkey. It is a perennial shrub or a small tree, growing up to 10 meters (Sarıbaş and Yaman, 2005). Most of the morphological, anatomical and ontogenic studies conducted in Crataegus have been concentrated on common species (Gyan and Woodell, 1987; Bura et al., 2016; Hamideh et al., 2012). To our knowledge, there are no detailed morphological and ontogenic studies that have been reported for Turkish endemic $C$. tanacetifolia. Since $C$. tanacetifolia is endemic to Turkey, there is not sufficient data regarding its 
morphological and ontogenic characteristics, hence we aimed to give a detailed account of these features. Information on the development of reproductive organs will help advance our understanding of reproductive behaviour and will thus contribute to attempts to solve taxonomic problems in Crataegus, a rather neglected genus in this respect.

\section{Materials and Method}

The materials were collected from natural habitats within the borders of Bolu, Lake Abant Nature Park (Turkey) and morphologically analysed under stereomicroscope (Olympus 970931). At least 50 samples were studied for each phase. After fixation process by FAA (Formalinglacial acetic acid-alcohol) solutions, they were embedded in paraffin blocks, sliced at $10 \mu \mathrm{m}$ by Leica RM2235 rotation microtome, stained with Delafield's hematoxylin, investigated by Olympus BH-2 light microscope. For scanning electron microscope (SEM) analysis, the material was fixed in $2.5 \%$ glutaraldehyde in $50 \mathrm{mM}$ cacodylate buffer, pH 7.0 (Platt et al., 1983), dehydrated with an increasing ethanol gradient: from $70 \%$ up to $100 \%$ and kept in hexamethyldisilazane solution at room temperature (Topcuoglu et al., 2009). After coating with $11 \mathrm{~nm}$ of gold by using an automated sputter coater, they were examined with JEOL JMS-59 10LV SEM.

\section{Results}

\subsection{Flower morphology}

Crataegus tanacetifolia has corymb type of inflorescence and the corymb contains 5-10 actinomorph, pentameric, hermaphrodite flowers (Fig. 1A). The flowers on the corymb are generally in different developmental stages. Gynoecium contains an ovary with 5 loculi and 5 free stigmas-styles (Fig. 1E). Twenty stamens surround the pistil (Fig. 1B,D). The flowers have 5 green, hairy sepals and 5 free, roundish, white petals. Receptacle is green and hairy (Fig. 1C). Measurements of the mature flower and flower parts of $C$. tanacetifolia were presented in Table 1 .

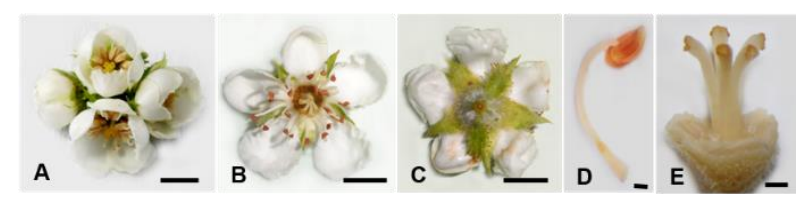

Figure 1. Morphology of the corymb and the flower of $C$. tanacetifolia. A. Corymb type of inflorescence, B. Upper view of mature flower with pistils, stamens and petals, C. Bottom view of mature flower with hairy sepals, D. Mature stamen, E. Gynoecium with 5 loculi ovary and 5 free stigmas-styles. Bar: $0.5 \mathrm{~mm}$ (D), 1 $\mathrm{mm}(\mathrm{E}), 1 \mathrm{~cm}(\mathrm{~A}), 0.5 \mathrm{~cm}(\mathrm{~B}, \mathrm{C})$.

Table 1. Measurements of mature flower and flower parts of $C$. tanacetifolia.

\begin{tabular}{|l|c|}
\hline Flower and flower parts & Measurement (mm) \\
\hline Lenght of the mature flower & $15 \pm 2$ \\
\hline Width of the mature flower & $12 \pm 3$ \\
\hline Lenght of the sepal & $9 \pm 2$ \\
\hline Lenght of the petal & $11 \pm 3$ \\
\hline Lenght of the stamen & $11 \pm 2$ \\
\hline Lenght of the pistil & $13 \pm 2$ \\
\hline
\end{tabular}

\subsection{Flower ontogeny}

Development starts with the differantiation of shoot apical meristem (Fig. 2A). Tunica, located at the tip of growth cone, consists of a few layers of cells. The diameter of the apical meristem increases as a consequence of cell division. Afterwards, growth cone swells due to the cell division at corpus (Fig. 2B). With the flattening of the growth cone and then swelling up of it, the transformation from bud to flower starts (Fig. 2C). Firstly, the apical flower bud of the corymb and then the lateral flower buds differantiate (Fig. 2D). Afterwards, floral organ primordia are generated at differantiated flower buds.

Floral organ formation starts with the formation of apical meristem. It differantiates as a roundish bulge from the vegetative meristem at growth points (Fig. 2E, Fig. 3A) and consists of well-ordered, thin walled small cells which have abundant cytoplasm and small vacuoli (Fig. 2F). Development of a flower starts with the transformation of the apical meristem to the floral meristem. During the transformation, lenght and width of the apical meristem increase and the apical apex becomes flattened (Fig. 2G, Fig. 3B). Therefore, the width of floral meristem (approximately $197 \mu \mathrm{m}$ ) is greater than that of apical meristem (approximately $181 \mu \mathrm{m}$ ). The floral meristem consist of well ordered, thin walled cell layers and the intercellular space of the cells are small. The cells have abundant cytoplasm, numerous vacuoli and a big nucleus which consist of a great number of nucleoli, indicates that the cells are very active in transcription (Fig. 2H).

The floral meristem gives rise to the floral organ primordia in advanced stages. Twenty stamen primordia, that are located very close to each other, differantiate as roundish bulges from the outer ring of the floral meristem (Fig. 2I,J, Fig. 3C,D). The flatness of floral meristem is still visible at this stage. Concomittant with the start of stamen primordia development, 5 roundish carpel primordia differantiate from the center of floral meristem and the flatness of the floral meristem can not be visible in this way (Fig. 2K).

While the stamens develop, the roundish shape of them begin to dissappear. Firstly anther and then filament differantiates. During this time, carpel primordia begin to develop and elongate (Fig. 2L). The extending carpel primordia create their own style, the lower part of the pistil becomes swollen and the origin of ovary and ovary loculi are formed. Stigma differantiates on the apex of the style in the advanced stage (Fig. 2M). During the initiation and development, the dimention of the flower bud and reproductive organs increase (Fig. 2N, Fig. 3E,F). Relationship between the flower bud size and flower development stages of $C$. tanacetifolia were presented in Table 2.

Table 2. Relationship between flower bud size and flower development stages in C. tanacetifolia.

\begin{tabular}{|l|l|l|}
\hline $\begin{array}{l}\text { Stage of flower } \\
\text { development }\end{array}$ & $\begin{array}{l}\text { Width of the } \\
\text { flower bud }(\boldsymbol{\mu m})\end{array}$ & $\begin{array}{l}\text { Lenght of the } \\
\text { flower bud }(\boldsymbol{\mu m})\end{array}$ \\
\hline Apical meristem & $535 \pm 21$ & $436 \pm 46$ \\
\hline Floral meristem & $552 \pm 36$ & $453 \pm 42$ \\
\hline $\begin{array}{l}\text { Stamen primordia } \\
\text { initiation }\end{array}$ & $560 \pm 14$ & $516 \pm 29$ \\
\hline Carpel primordia initiation & $573 \pm 23$ & $524 \pm 32$ \\
\hline
\end{tabular}




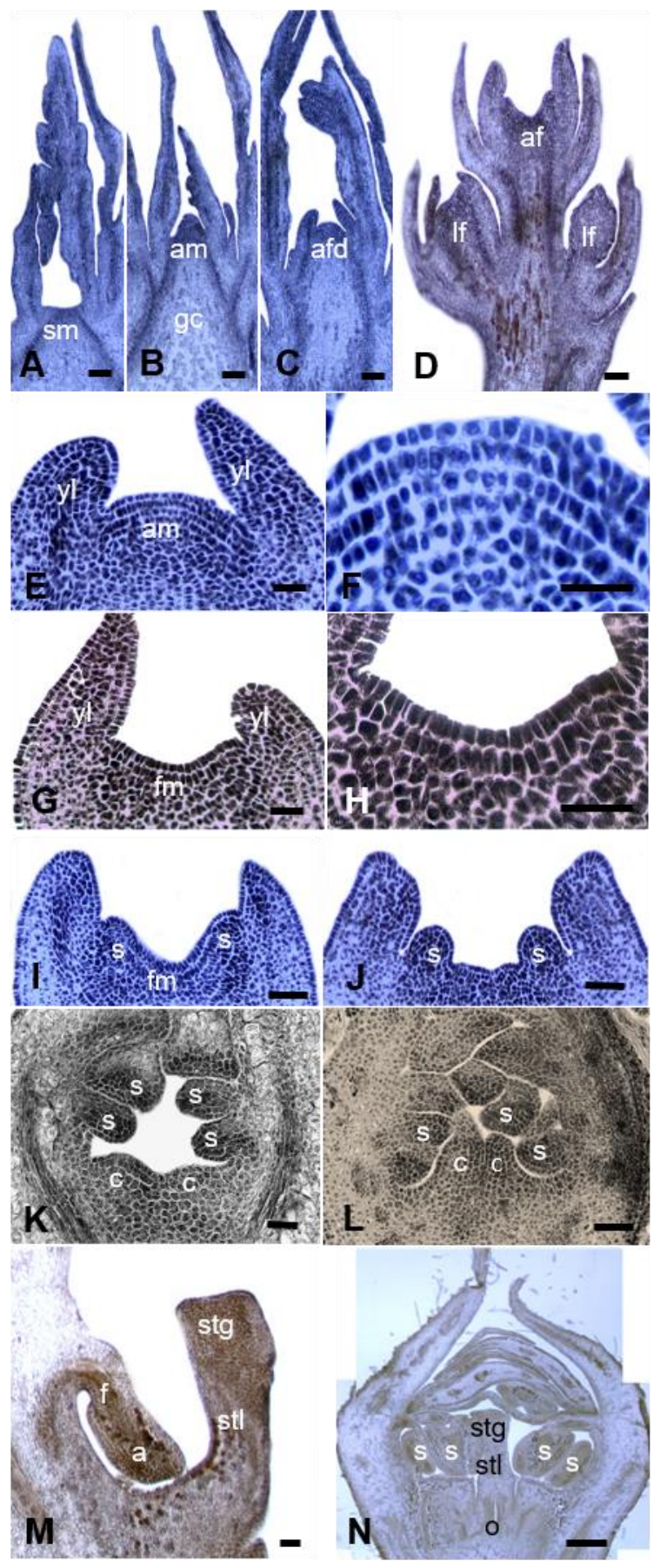

Figure 2. Flower ontogeny in C. tanacetifolia. A. Straight and flat shoot meristem, B. Shoot apical meristem and swelling of growth cone, C. Differantiation of apical flower bud, D. Lateral flower bud differantiation and becoming recognizable of corymb. E. Apical meristem, F. The cells of apical meristem, G. Floral meristem, H. The cells of floral meristem, I. Initiation of stamen primordia from floral meristem, J. Development of stamen primordia, K. Initiation of carpel primordia, L. Growing of carpel primordia, M. One of the 5 young pistil and one of the 20 young stamen, N. Mature flower. sm: Shoot meristem, am: Apical meristem, gc: Growth cone, afd: Apical flower draft, af: Apical flower, lf: Lateral flower. yl: Young leaf, fm: Floral meristem, s: Stamen primordium, a: Anther, f: Filament, c: Carpel primordium, stg: Stigma, stl: Style, o: Ovary. Bar: $50 \mu \mathrm{m}$ (E-H, I-M), $100 \mu \mathrm{m}$ (A-D), $200 \mu \mathrm{m}(\mathrm{N})$.

\section{Discussions}

The corymbs of C. tanacetifolia and C. yaltirikii Dönmez contain 5-10 flowers, the corymb of $C$. coriifolia Sharifnia
\& Zarrinkolah (Sharifnia et al., 2016) bears 15 flowers and the corymb of $C$. ambigua Mey. bears 20 flowers (Tuyakova et al., 2016). The flowers of Crataegus are pentameric and petals are generally white-pink (Dönmez, 2004). Flower sizes of Maloideae are generally $3.4 \mathrm{~mm}$ and $4.1 \mathrm{~mm}$. The number of organs is not related to the size of the flowers. For instance, $C$. suksdorfii Lindl. and $C$. douglasii Lindl. have larger flowers than $C$. rivularis Nutl. and $C$. brockwayae Sarg.. Crataegus rivularis Nutl. has more stamens than $C$. douglasii Lindl., but has less stamen than C. brockwayae Sarg. (Evans and Dickinson, 1996). The number of stamen differs from species to species in Crataegus (Evans and Dickinson, 1996). The flowers generally contain 10 stamens as in C. transmississippiensis Sarg. and C. galli L. or 20 stamens as in C. tanacetifolia, $C$. submollis Sarg., C. canadensis Sarg., C. punctata Jacq. (Phipps, 2012). The number of ovary loculi can also differ in Crataegus species. Crataegus tanacetifolia has 1 ovary with 5 loculi, the ovary of $C$. galli has 1-2 loculi and the ovary of $C$. punctata has 2-5 loculi. Each of the loculi of these species are linked to the style as in $C$. tanacetifolia.

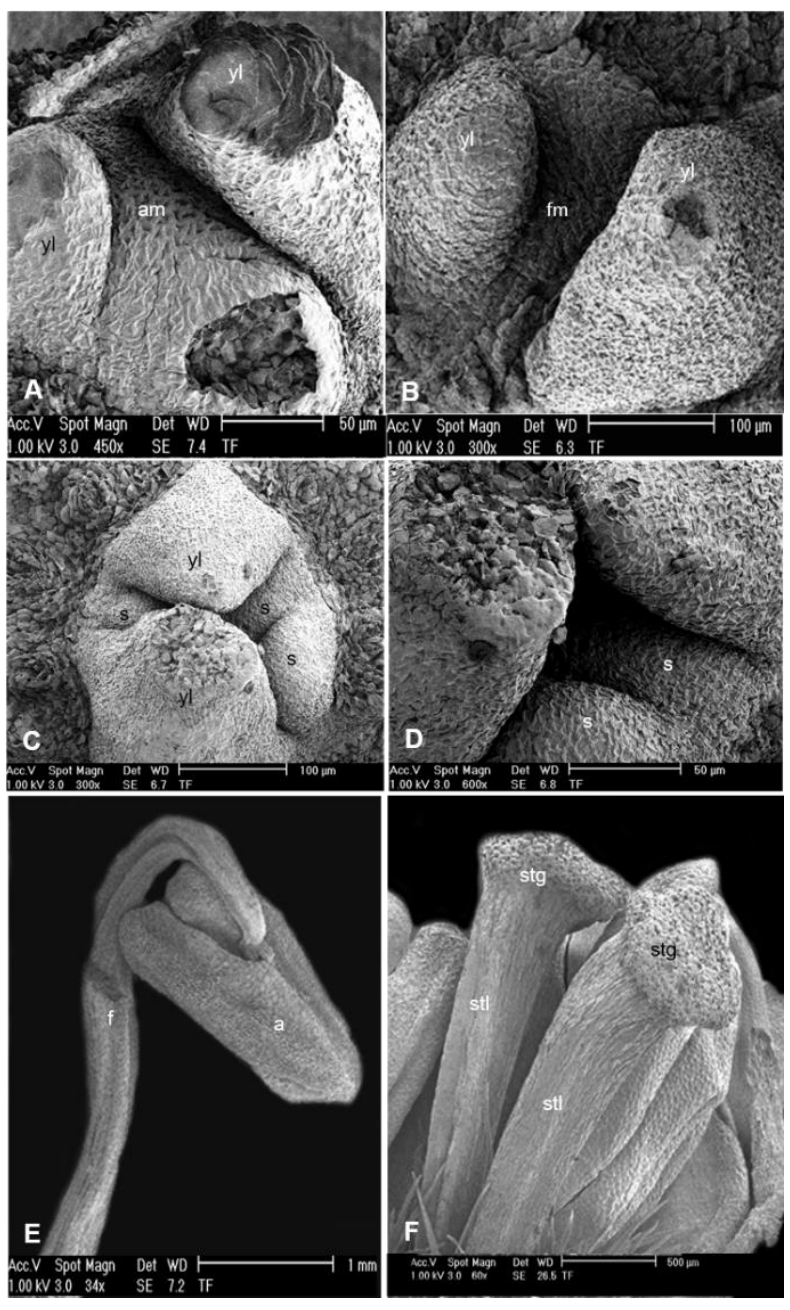

Figure 3. SEM micrograph of the flower ontogeny in $C$. Tanacetifolia. A. Apical meristem, B. Floral meristem, C. Stamen primordia initiation, D. Stamen primordia, E. 1 of the 20 mature stamen, F. 2 of the 5 mature pistil. am: Apical meristem, fm: Floral meristem, yl: Young leaf, s: Stamen primordia, a: Anther, f: Filament, stg: Stigma, stl: Style.

Most angiosperms produce hermaphrodite flowers with functional male and female sex organs within the same flower (Aryal and Ming, 2014). During the early stages of 
floral organ development, all floral organ primordia form in male and female flowers. In males, the gynoecium develops as a sterile, undifferentiated rod, while in females, anther development arrests soon after the anther primordia form, then the anthers degenerate (Juarez and Banks, 1998). Therefore, the further development of stamens or pistils is very important in determining the sex of the flower. It is thought that sex is determined by the selective inhibition of gynoecium or androecium development in hermaphrodite flower. Also, the determination process involves the differentiation of gametophyte in pistil or stamen (Dellaporta and Urrera, 1993). For instance, sex determination in pistillate flower of Zea mays arises as a result of programmed cell death of stamen primordia (Cheng et al., 1983). Due to the hermophroditism, there are no atrophy or cell death on sexual organ primorida of $C$. tanacetifolia.

The developmental stages from the physiological differentiation of flower buds to the blooming of flowers have been studied by many researchers. Durner and Poling (1985) have divided the flowering into 4 stages: induction, initiation, differentiation and development. The floral induction occurs in the leaf upon exposure to a stimulus which ultimately results in the production of a flower bud at a shoot meristem (Durner, 2015). The initiation includes physiological and morphological changes occurring in the meristem upon receipt of stimuli from the leaf. Tal et al. (2017) indicated that enlargement and doming of the shoot apical meristem is a hallmark of the transition from vegetative growth to flowering. According to Evans and Dickinson (1996), the initiation of the flower buds starts with the transformation of apical meristem to the floral meristem. The morphological changes, observed during the conversion of apical meristem to floral meristem, resemble the ones in Prunus avium L. and P. Persica (L.) Batsch; apical meristem flattens and radially extends (Engin and Ünal, 2007). According to Durner and Poling (1985), differentiation is the development of specific floral organs on a single flower or of flowers on a single inflorescence, and development is the macroscopic production of flowers.

As in other plants (Uhl, 2011), all floral organ primordia in C. tanacetifolia develop as a result of periclinal division of floral meristem cells. In $C$. tanacetifolia, $C$. suksdorfii Lindl., C. douglasii Lindl. and C. rivularis Nutl., the first differentiated sex organs from floral meristem are stamens. Stamen primordia arise in roundish bulge forms as they do in $P$. avium and $P$. persica (Engin and Ünal, 2007). In Maloideae, 20 stamen differantiates in 1-3 rings. However, in C. tanacetifolia, 20 stamen primordia, that are located very close to each other, differantiate as roundish bulges from the outer 1 ring of the floral meristem and they emerge synchronized as they do in Erigeron philadelphicus L. (Harris et al., 1991). Stamen primordia arise out of the sides of floral meristem, as Dadpour et al. (2011) stated, and in stages where stamen primordia start emerging, the flatness of floral meristem starts to become gradually convex.

Female organ development starts with formation of carpel primordium in the center of floral meristem in $C$. tanacetifolia, as it is a usual manner in flowering plants (Gasser and Beers, 1993). But in Maloideae the time of differantiation of carpel primordia can differ. For instance, carpel primordia differantiates after all stamen primordia have achieved a nearly hemispherical shape in $C$. suksdorfii (Evans and Dickinson, 1996). But they differantiate shortly after the stamen initiation in C. tanacetifolia. The carpel primordia, which just arise in $C$. tanacetifolia, are not as roundish as stamen primordia. Uhl (2011) mentioned that various floral organs those differentiate out of floral meristem, might be morphologically different.

\section{Acknowledgments}

This work was supported by the Research Foundation of Marmara University (BAPKO no. FEN-C-DRP- 1205140169).

\section{References}

Aryal R, Ray M (2014). Sex determination in flowering plants: papaya as a model system. Plant Science 217: 56-62.

Benli M, Yiğit N, Geven F, Güney K, Bingöl Ü (2008). Antimicrobial activity of endemic Crataegus tanacetifolia (Lam.) Pers and observation of the inhibition effect on bacterial cells. Cell Biochemistry and Function 26(8): 844-851.

Bura FT, Firuzja RA, Nemati F (2016). Cytotoxic effect of the flower and leaf bud extract of Crataegus microphylla c. koch on hela cell line. IIOAB Journal 7(4): 214-218.

Campbell CS, Evans RC, Morgan DR, Dickinson TA, Arsenault MP (2007). Phylogeny of subtribe Pyrinae (formerly the Maloideae, Rosaceae): limited resolution of a complex evolutionary history. Plant Systematics and Evolution 266(1): 119145.

Chang WT, Dao J, Shao ZH (2005) Hawthorn: potential roles in cardiovascular disease. The American Journal of Chinese Medicine 33(01): 1-10.

Cheng P, Greyson C, Walden D (1983). Organ initiation and the development of unisexual flowers in the tassel and ear of Zea mays. American Journal of Botany 70: 450-462.

Çetinbaş A, Ünal M (2012). Comparative ontogeny of hermaphrodite and pistillate florets in Helianthus annuus L. (Asteraceae). Notulae Scientia Biologicae 4(2): 30-40.

Dadpour MR, Naghiloo S, Neycaran SF (2011). The development of pistillate and perfect florets in Xeranthemum squarrosum (Asteraceae). Plant Biology 14: 234-243.

Davis PH, Browicz K (1972) Flora of Turkey and the East Aegean Islands. Edinburgh: Edinburgh Univ. Press.

Dellaporta SL, Calderon-Urrea A (1993). Sex determination in flowering plants. The Plant Cell Online 5(10):1241-1251.

Dong P, Pan L, Zhang X, Zhang W, Wang X, Jiang M, Chen Y, Duan Y, Wu H, Xu Y, Zhang P, Zhu Y (2017) Hawthorn (Crataegus pinnatifida Bunge) leave flavonoids attenuate atherosclerosis development in apoE knock-out mice. Journal of Ethnopharmacology 198:479-488. 
Dönmez AA (2004). The genus Crataegus L. (Rosaceae) with special reference to hybridisation and biodiversity in Turkey. Turkish Journal of Botany 28: 29-37.

Durner EF (2015). Photoperiod affects floral ontogeny in strawberry (Fragariax ananassa Duch.) plug plants. Scientia Horticulturae 194: 154-159.

Durner EF, Poling EB (1985). Comparison of three methods for determining the floral or vegetative status of strawberry plants. Journal of the American Society for Horticultural Science 110: 808-811.

Engin H, Ünal A (2007). Examination of flower bud initiation and differentiation in sweet cherry and peach by scanning electron microscope. Turkish Journal of Agriculture and Forestry 31(6): 373-379.

Evans RC, Dickinson TA (1996). North American black-fruited hawthorns. II. Floral development of 10-and 20-stamen morphotypes in Crataegus section Douglasii (Rosaceae: Maloideae). American Journal of Botany 83(8):961-978.

Gasser S, Beers K (1993). Pistil development. Plant Cell 5(10): 1231-1239.

Gyan KY, Woodell SRJ (1987). Flowering phenology, flower colour and mode of reproduction of Prunus spinosa L. (Blackthorn); Crataegus monogyna Jacq. (Hawthorn); Rosa canina L. (Dog Rose); and Rubus fruticosus L. (Bramble) in Oxfordshire, England. Functional Ecology 1(3): 261-268.

Hamideh R, Ahmad M, Sedigheh A, Fariba S, Sedigheh M (2012). A study of microsporogenesis and pollen morphology in Crataegus babakhanloui (Rosaceae). Advances in Environmental Biology 6(11): 2986-2991.

Harris EM, Tucker SC, Urbatsch LE (1991) Floral initiation and early development in Erigeron philadelphicus (Asteraceae). American Journal of Botany 78(1): 108-121.

Juarez C, Banks JA (1998). Sex determination in plants. Current Opinion in Plant Biology 1(1): 68-72.

Kinney MS, Columbus JT, Friar EA (2008). Unisexual flower, spikelet, and inflorescence development in monoecious/dioecious Bouteloua dimorpha (Poaceae, Chloridoideae). American Journal of Botany 95(2): 123-132.

Lund JA, Brown PN, Shipley PR (2017). Differentiation of Crataegus spp. guided by nuclear magnetic resonance spectrometry with chemometric analyses. Phytochemistry 141: 11-19.

Phipps JB (2012). Critical taxa in Crataegus series Molles (Rosaceae): Typifications, new combinations, and taxonomic review. Phytoneuron 78:1-23.

Platt AKA, Oross JW, Thomson WW (1983). Ultrastructural study of the development of oil cells in the mesocarp of avocado fruit. Botanical Gazette 144(1): 49-55.

Rohrer JR, Robertson KR, Phipps JB (1994). Floral morphology of Maloideae (Rosaceae) and its systematic relevance. American Journal of Botany 81(5): 574-581.

Saribas M, Yaman B (2005). Wood anatomy of Crataegus tanacetifolia (Lam.) Pers. (Rosaceae), endemic to Turkey. International Journal of Botany 1(2): 158-162.

Sharifnia F, Zarrinkolah O, Salimpour F (2016). Crataegus coriifolia sp. nov. (Rosaceae) from Iran. Nordic Journal of Botany 34(6): 735-738.

Tal L, Friedlander G, Gilboa NS, Unger T, Gilad S, Eshed Y (2017). Coordination of meristem doming and the floral transition by late termination, a kelch repeat protein. The Plant Cell tpc-00030.

Tassell MC, Kingston R, Gilroy D, Lehane M, Furey A (2010). Hawthorn (Crataegus spp.) in the treatment of cardiovascular disease. Pharmacognosy Reviews 4(7): 32-41.

Topçuoğlu N, Selvi N, Dokumaci E (2009). The comparison of critical point drying and drying with hexamethyldisilazane methods for the preparation of mice tissues for scanning electron microscopy ii. Lung and stomach findings. Anadolu University Journal of Science and Technology 1: 127-132.

Tuyakova AT, Imanbayeva AA, Duysenova NI, Ishmuratova MY (2016). Anatomical structure study of aerial organs of Crataegus ambigua CA Mey.. Biosciences Biotechnology Research Asia 13(3): 1303-1309.

Uhl WN (2011). Developmental studies in Ptychosperma (Palmae). II. The staminate and pistillate flowers. American Journal of Botany 63(1): 97-109.

Vitalini S, Tomè F, Fico G (2009). Traditional uses of medicinal plants in Valvestino (Italy). Journal of Ethnopharmacology 121(1): 106-116. 